\title{
Effects of salinity and possible interactions with temperature and pH on growth and photosynthesis of Halophila johnsonif Eiseman
}

\begin{abstract}
The effects of salinity, temperature, and $\mathrm{pH}$ variations on growth, survival, and photosynthetic rates of the seagrass Halophila johnsonii Eiseman were examined. Growth and survival responses to salinity were characterized by aquarium experiments in which plants were exposed to seven different salinity treatments $(0,10,20,30,40,50$, and 60 psu) during 15 days. Photosynthetic behavior was assessed for short-term salinity exposures $(1$ or $20 \mathrm{~h})$ by incubation experiments in biological oxygen demand (BOD) bottles and by measuring photosynthesis versus irradiance (PI) responses in an oxygen electrode chamber. In the bottle experiments the possible effects of interactions between salinity and temperature $\left(15,25\right.$, and $\left.35^{\circ} \mathrm{C}\right)$ or $\mathrm{pH}(5,6,7$, and 8.2) were also examined. Growth and survival of $H$. johnsonii were significantly affected by salinity, with maximum rates obtained at $30 \mathrm{psu}$. Salinity also altered the parameters of the PI curves. Light-saturated photosynthesis $\left(P_{\max }\right)$ and the photosynthetic efficiency at subsaturating light $(\alpha)$ increased significantly up to an optimum of $40 \mathrm{psu}$, decreasing again at the highest salinities. Dark respiration rates and compensating irradiance $\left(I_{\mathrm{c}}\right)$ showed minimum values at 40 and $50 \mathrm{psu}$, while light-saturation point $\left(I_{\mathrm{k}}\right)$ was maximum at $30-50$ psu. An interaction between salinity and temperature was not found although an increase of temperature alone produced an increase in $\alpha, P_{\max }$, respiration rates, and $I_{\mathrm{k}}$. An interaction between salinity and $\mathrm{pH}$ was only found in the $P_{\max }$ response: $P_{\max }$ increased with
\end{abstract}

Communicated by S.A. Poulet, Roscoff

Y. F. Torquemada $(\bowtie) \cdot$ J. L. S. Lizaso

Unidad de Biología Marina,

Departamento de Ciencias del Mar y Biología Aplicada, University of Alicante, P.O. Box 99, 03080 Alicante, Spain E-mail: Yolanda.Fernandez@ua.es

Tel.: + 34-9-65903400

Fax: + 34-9-65903815

M. J. Durako

Department of Biological Sciences, Center for Marine Science, University of North Carolina at Wilmington,

5600 Marvin Moss Ln, Wilmington, NC 28409, USA
$\mathrm{pH}=5$ at $30 \mathrm{psu}$. In addition, reducing the $\mathrm{pH}$ increased $\alpha$ significantly. In the BOD bottles experiment a significant reduction in the dark respiration with decreasing $\mathrm{pH}$ was observed, but the opposite trend was observed in the photosynthetic rate. These results suggest that the endemic seagrass $H$. johnsonii could be negatively affected by hypo- or hypersalinity conditions, although salinity changes did not seem to alter the tolerance of this species to other environmental factors, such as temperature or $\mathrm{pH}$.

\section{Introduction}

Few studies are known about the physiological tolerances of Halophila johnsonii (Dawes et al. 1989; Durako et al. 2003), probably due to its restricted geographical distribution and low abundance where it appears (Kenworthy 1997). This species is also characterized by having a limited reproductive capacity; no male flowers have been observed, thus, sexual reproduction may not occur. The lack of sexual reproduction and patchy distribution make this species very vulnerable to anthropic and natural disturbances (Durako and Wettstein 1994). However, $H$. johnsonii has a significant ecological importance; it stabilizes sediments and has a significant function in nutrient cycling, due to its rapid turnover (Kenworthy 1997). For all these reasons it is considered a rare species and it has been the only seagrass catalogued as threatened by the Endangered Species Act $(63$ FR 49035) in the USA (Durako and Wettstein 1994; Kenworthy 1997).

$H$. johnsonii inhabits a $200 \mathrm{~km}$ segment of the coastal lagoons along the east coast of Florida, between Sebastian Inlet and north Biscayne Bay. It has been found in a wide range of environmental conditions, suggesting that it can be considered more eurybiotic than the other species of the same genera (Kenworthy 1997). Field observations indicate that it occurs in waters with temperatures ranging from 21 to $36^{\circ} \mathrm{C}$ and 
salinities between 24.3 and 43 psu (Eiseman and McMillan 1980) while in a laboratory experiment Dawes et al. (1989) reported a maximum photosynthesis for this species at $25-35$ psu and $30^{\circ} \mathrm{C}$.

Salinity is a constant factor in the open sea, although it can fluctuate in more closed environments (lagoons, bays, estuaries, etc.) due to natural freshwater inputs or human activities, such as the reduction in freshwater inputs within the coastal lagoons of South Florida as a consequence of the freshwater management practices (Montague and Ley 1993; Hicks et al. 1998; Kamermans et al. 1999; Irlandi et al. 2002; Lirman and Cropper 2003), wastewater disposal, or the development of seawater desalination plants (Tomasko et al. 1999). Although most seagrasses can tolerate short-term salinity fluctuations, salinity variations will significantly affect some of the biochemical processes involved in photosynthesis and growth, determining the biomass, distribution, and productivity of these species (Montague and Ley 1993; Hillman et al. 1995; Chesnes and Montague 2001). Experimental studies on seagrass tolerance to salinity changes have shown that most species have optimum productivity at around oceanic salinity (Ogata and Matsui 1965; McMillan and Moseley 1967; Biebl and McRoy 1971; Drysdale and Barbour 1975; Hillman et al. 1995; Doering and Chamberlain 1998), though some species have optima at lower salinities (Kamermans et al. 1999; van Katwijk et al. 1999). These investigations have demonstrated that extreme or suboptimal salinities can produce negative alterations of their photosynthetic rate (Biebl and McRoy 1971; Kerr and Strother 1985; Dawes et al. 1987, 1989), metabolism (van Katwijk et al. 1999), reproduction (Ramage and Schiel 1998), growth (McMillan and Moseley 1967; Walker 1985; Walker and McComb 1990), and survival (Vermaat et al. 2000).

Along with salinity levels, other important environmental factors can vary, such as temperature or $\mathrm{pH}$, also affecting the distribution and growth of several seagrass species (Ogata and Matsui 1965; Biebl and McRoy 1971; Hillman et al. 1995). These variations can be natural or produced by certain human activities, such as discharges from a desalination plant. Actually desalination is a growing industry at Florida but there is little information about its potential adverse environmental impacts. Brine discharge has an elevated salinity, a relatively high temperature, and low pH (Lattemann and Höpner 2003). Temperature can alter the metabolism or cause mortality at extreme values (Biebl and McRoy 1971; Drysdale and Barbour 1975; Drew 1979; Marsh et al. 1986). The principal influence of $\mathrm{pH}$ is on the concentration and form of available carbonates (Invers et al. 1997), which affect the photosynthesis of marine angiosperms (Beer and Waisel 1979). Few studies have investigated the effect of interactions or co-variations of these factors on seagrasses (Biebl and McRoy 1971; Dawes et al. 1989; Ralph 1999).

The main objective of the present work was to determine the responses of $H$. johnsonii to salinity in different laboratory-controlled experiments. Growth and mortality rates of this species were examined for medium-term exposures (15 days), while photosynthesis versus irradiance $(\mathrm{PI})$ behavior and respiration were investigated for short-term salinity exposures (1 or $20 \mathrm{~h}$ ), including the study of possible interactions with $\mathrm{pH}$ and temperature.

\section{Materials and methods}

\section{Plant material}

Intact vegetative plants of $H$. johnsonii were collected from a shallow bed at Haulover Park, in northern Biscayne Bay, FL (USA, $25^{\circ} 55^{\prime} \mathrm{N} ; 80^{\circ} 07^{\prime} \mathrm{W}$ ) in 2001 . Plants were transported to the seawater-supplied greenhouse of the Center for Marine Science at Wilmington, NC and allowed to acclimate to laboratory conditions for 1 year prior to experimentation. During this time, plants were maintained in aquariums with a salinity of $30-33$ psu.

In November 2002, H. johnsonii's responses to salinity were monitored through two types of experiments, a medium-term series (15 days) in which growth and survival rates were evaluated at different salinities and several short-term $(1$ or $20 \mathrm{~h})$ photosynthetic tests in which plants were subjected to rapid salinity exposures.

\section{Growth experiment}

Transplant units, consisting of a rhizome segment containing an apical shoot with three leaf pairs, were selected and placed in individual and open plastic pots of $125 \mathrm{~cm}^{3}$ with sandy-mud sediment. The transplant units were acclimated in a 501 glass aquarium at $30 \mathrm{psu}$ for $24 \mathrm{~h}$, prior to the start of the experiment. Transplant units were randomly chosen from the acclimation aquarium and placed in seven different salinity treatments $(0,10,20,30,40,50$, and $60 \mathrm{psu})$ replicated in two well-aerated 501 glass aquariums (we used a total of 14 aquariums). Four transplant units were used per aquarium. Before the experiments, the plants were allowed to acclimate to each $10 \mathrm{psu}$ variation for 3 days because previous studies suggest that acclimation to salinity variations permits a greater tolerance to osmotic stress than an instantaneous transfer (Ralph 1998).

Control-treatment salinity was $30 \mathrm{psu}$, considered the average salinity of the waters where $H$. johnsonii has been found, and it is within the optimal range described for its photosynthetic rates (Eiseman and McMillan 1980; Dawes et al. 1989). Increased salinity treatments were produced by adding Instant Ocean salt (Aquarium Systems, Ohio, USA) free of added nutrients to seawater, while lower salinities were obtained by diluting seawater with demineralized freshwater. Salinity values in each aquarium were controlled and maintained ( $\pm 1.5 \mathrm{psu})$ during the exposure time. Temperature 
Table 1 Summary of the ANOVA testing the effects of salinity treatments (0-60 psu at 10 psu increments) on growth and mortality of $H$. johnsonii

\begin{tabular}{llllll}
\hline Parameter & Effect & $d f$ & MS & $F$ & $P$ \\
\hline Growth & Salinity & 6 & 23.8631 & 14.22 & $* *$ \\
& Aquaria & 7 & 1.6786 & 0.23 & ns \\
& Error & 42 & 7.4405 & & $* *$ \\
Mortality & Salinity & 6 & 0.5357 & 10.00 & ns \\
& Aquaria & 7 & 0.0536 & 0.27 & \\
& Error & 42 & 0.1964 & &
\end{tabular}

$n s$ non-significant

${ }^{* *} P<0.01$

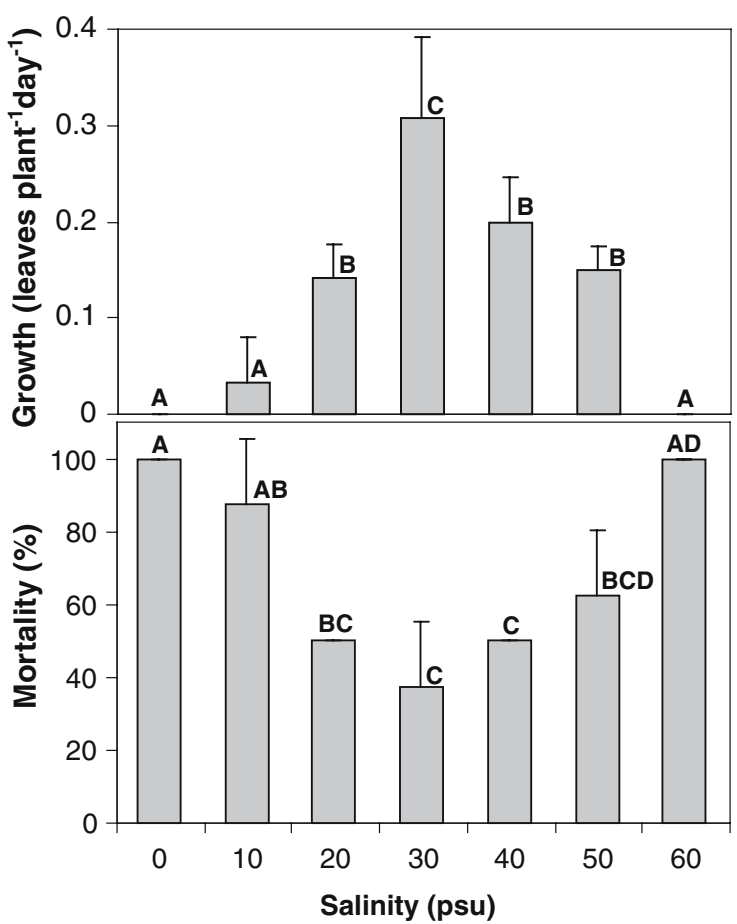

Fig. 1 Halophila johnsonii growth (leaf production per plant and day) and percent mortality at different salinities. Means with different letters are statistically different at $P<0.05$ (bars represent standard error)

during the experiment varied between 25 and $32^{\circ} \mathrm{C}$. Irradiance measured at the sediment surface was 500 $1400 \mu \mathrm{mol}$ quanta $\mathrm{m}^{-2} \mathrm{~s}^{-1}$ of photosynthetically active radiation (PAR, $\lambda=400-700 \mathrm{~nm}$ ) during the day, measured with a LiCor 193 SA spherical quantum sensor, with a light regime adjusted to $12 \mathrm{~h}$ light and $12 \mathrm{~h}$ dark using supplemental natural spectrum halogen lighting.

Net shoot production was estimated by a marking method, consisting of a fine plastic fiber placed on the sediment on the same position of the terminal leaf pair of each rhizome (Short and Duarte 2001). At the end of the experiment (duration 15 days), the number of new leaf pairs produced and the mortality rate were recorded.

\section{Photosynthetic experiments}

In order to estimate the effects of rapid salinity exposures, a series of experiments were conducted to determine acute responses (treatment exposures of 1 and $20 \mathrm{~h}$ ) of photosynthesis and respiration on this seagrass to a wide range of salinities (from 0 to $60 \mathrm{psu}$ ). In addition, a second series of experiments were conducted to examine possible interactions between salinity, temperature, and $\mathrm{pH}$. Experimental salinity media were prepared by adding Instant Ocean nutrient-free salt to demineralized water; $\mathrm{pH}$ was reduced with $\mathrm{H}_{2} \mathrm{SO}_{4}$. Because prolonged times in closed systems can change the seawater $\mathrm{pH}$, it was measured at the beginning and end of each incubation.

Net oxygen evolution was measured with a Hansatech oxygen electrode system (Clark type) calibrated with $\mathrm{N}_{2}$ and air-saturated water. Two randomly selected leaves of $H$. johnsonii were placed in the closed reaction chamber with $2 \mathrm{ml}$ of stirred treatment solution and allowed to equilibrate in the dark for $10 \mathrm{~min}$. Before each incubation, water in the electrode chamber was sparged with nitrogen to reduce the initial oxygen concentration to about $25 \%$ of saturation because photosynthesis can be negatively affected by elevated concentrations of $\mathrm{O}_{2}$ (Beer 1989). After equilibration, an initial oxygen consumption reading over a $2 \mathrm{~min}$ interval was made to determine the dark respiration rate. Leaves were then subjected to 15 light levels, in increasing order, ranging from 10 to $823 \mu \mathrm{mol}$ quanta $\mathrm{m}^{-2} \mathrm{~s}^{-1}$ of PAR, with $1 \mathrm{~min}$ of equilibration between each 2 min photosynthetic measurement interval. Irra-
Table 2 Summary of the oneway ANOVA testing the effects of salinity treatments $(0-60 \mathrm{psu}$ at 10 psu increments) on photosynthetic parameters: $\alpha$ photosynthetic efficiency at subsaturating light, $P_{\max }$ production at saturating irradiance, $I_{\mathrm{c}}$ compensation irradiance, $I_{\mathrm{k}}$ saturating irradiance and dark respiration ${ }^{*} P<0.05$;

${ }^{* *} P<0.01 ;{ }^{* * *} P<0.001$

\begin{tabular}{|c|c|c|c|c|c|}
\hline Parameter & Effect & $d f$ & MS & $F$ & $P$ \\
\hline $\begin{array}{l}\alpha\left(\mu \mathrm{mol} \mathrm{O} \mathrm{O}_{2} \mathrm{~g}^{-1} \mathrm{dw} \mathrm{h} \mathrm{h}^{-1}\right) \\
\times\left(\text { umol guanta } \mathrm{m}^{-2} \mathrm{~s}^{-1}\right)^{-1}\end{array}$ & $\begin{array}{l}\text { Salinity } \\
\text { Error }\end{array}$ & $\begin{array}{l}6 \\
14\end{array}$ & $\begin{array}{l}21.3753 \\
2.0056\end{array}$ & 10.66 & $* * *$ \\
\hline$P_{\max }\left(\mu \mathrm{mol} \mathrm{O} \mathrm{g}^{-1} \mathrm{dw} \mathrm{h}^{-1}\right)$ & $\begin{array}{l}\text { Salinity } \\
\text { Error }\end{array}$ & $\begin{array}{l}6 \\
14\end{array}$ & $\begin{array}{l}2.0050 \\
98848.62 \\
6115.99\end{array}$ & 16.16 & $* * *$ \\
\hline Respiration $\left(\mu \mathrm{mol} \mathrm{O} \mathrm{O}^{-1} \mathrm{dw} \mathrm{h}^{-1}\right)$ & $\begin{array}{l}\text { Salinity } \\
\text { Error }\end{array}$ & $\begin{array}{l}6 \\
14\end{array}$ & $\begin{array}{l}1034.896 \\
235.911\end{array}$ & 4.39 & $* *$ \\
\hline$I_{\mathrm{c}}\left(\mu \mathrm{mol}\right.$ quanta $\left.\mathrm{m}^{-2} \mathrm{~s}^{-1}\right)$ & $\begin{array}{l}\text { Salinity } \\
\text { Error }\end{array}$ & $\begin{array}{l}6 \\
14\end{array}$ & $\begin{array}{l}49.5248 \\
7.0358\end{array}$ & 7.04 & $* *$ \\
\hline$I_{\mathrm{k}}\left(\mu \mathrm{mol}\right.$ quanta $\left.\mathrm{m}^{-2} \mathrm{~s}^{-1}\right)$ & $\begin{array}{l}\text { Salinity } \\
\text { Error }\end{array}$ & $\begin{array}{l}6 \\
14\end{array}$ & $\begin{array}{l}385.6378 \\
95.4649\end{array}$ & 4.04 & $*$ \\
\hline
\end{tabular}




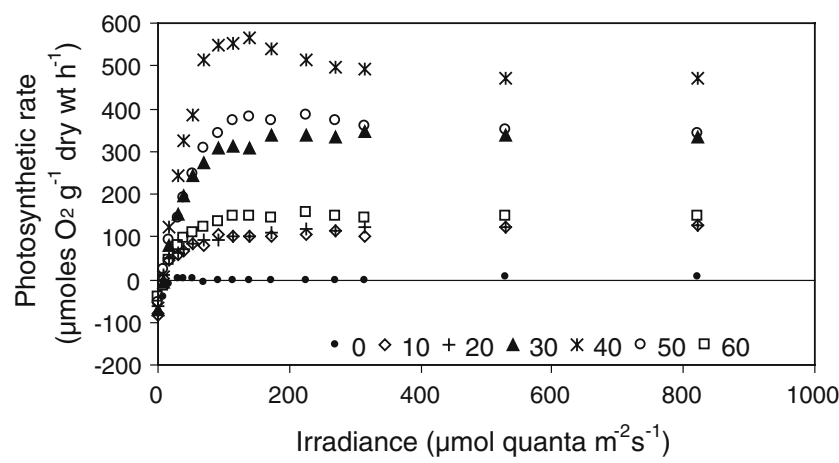

Fig. 2 Photosynthesis versus irradiance responses of Halophila johnsonii leaves exposed to different salinities. Symbols represent the average of three replicates

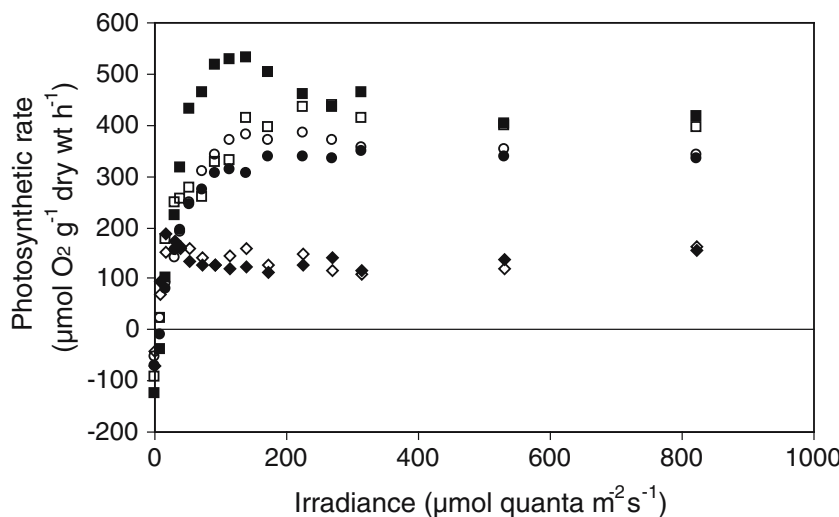

Fig. 3 Photosynthesis versus irradiance responses of Halophila johnsonii leaves exposed to different salinities and temperatures. Symbols represent the average of three replicates. Diamonds represent temperature $=15^{\circ} \mathrm{C}$, circles $T=25^{\circ} \mathrm{C}$, and squares

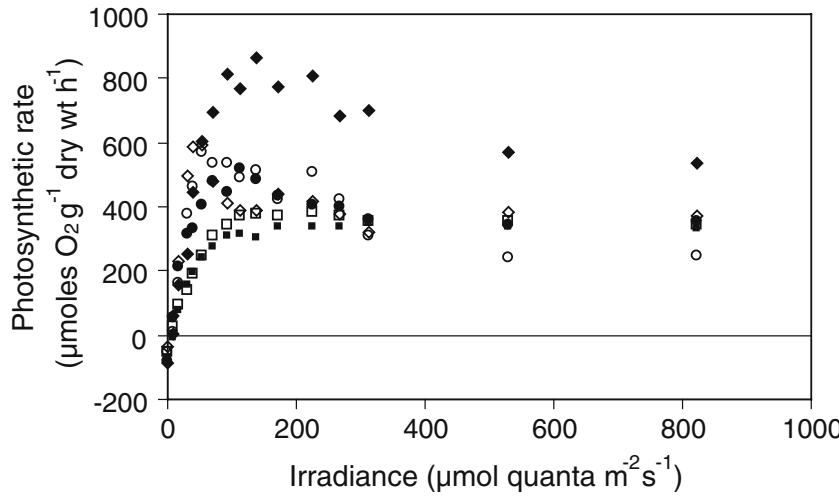

Fig. 4 Photosynthesis versus irradiance responses of Halophila johnsonii leaves exposed to different salinities and $\mathrm{pH}$ values. Symbols represent the average of three replicates. Diamonds represent $\mathrm{pH}=5$, circles $\mathrm{pH}=6$, and squares $\mathrm{pH}=8.2$. Filled symbols salinity $=30$ psu and open symbols salinity $=50$ psu
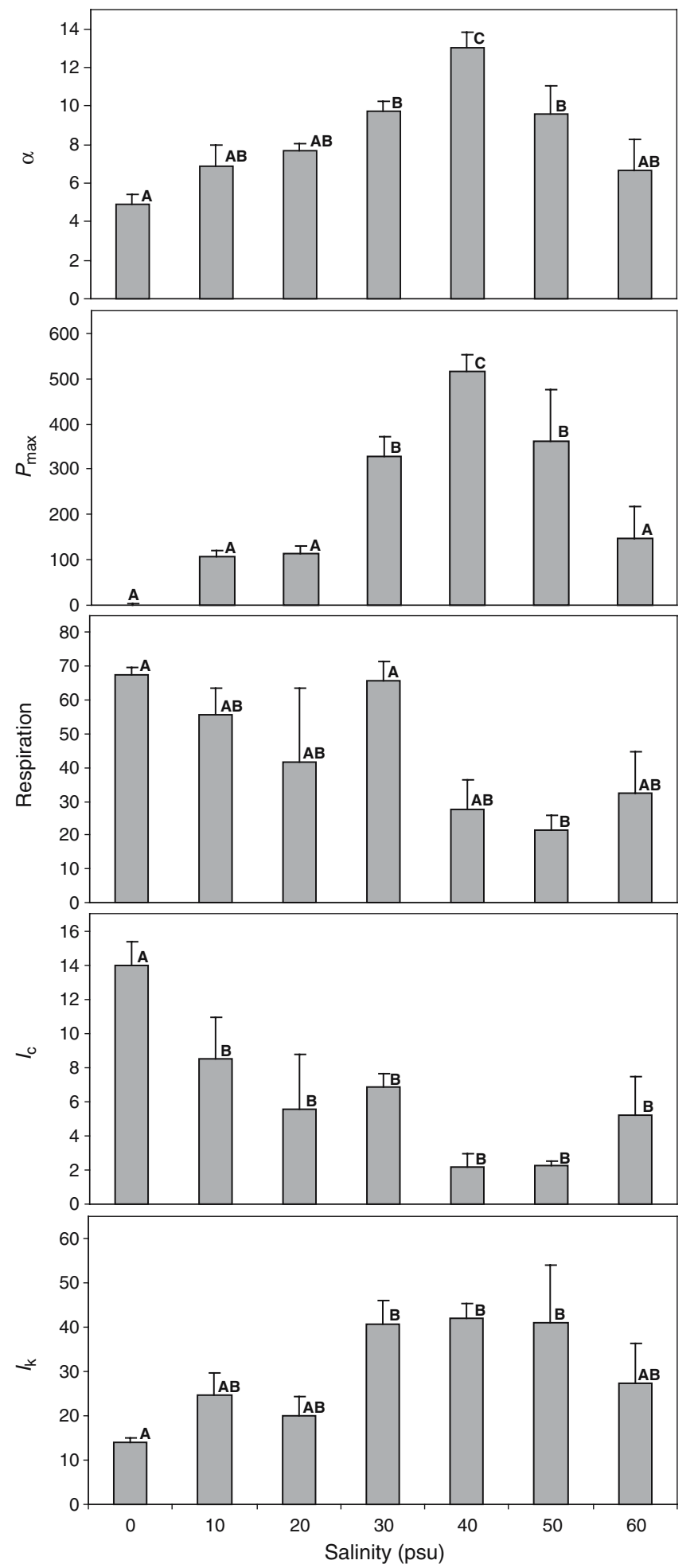

Fig. 5 Photosynthetic parameters at different salinities $\left[\alpha\left(\mu \mathrm{mol} \mathrm{O}_{2}\right.\right.$ $\left.\mathrm{g}^{-9} \mathrm{dw} \mathrm{h}^{-1}\right) \times\left(\mu \mathrm{mol} \text { quanta } \mathrm{m}^{-2} \mathrm{~s}^{-1}\right)^{-1}, P_{\max }$ and respiration rate $\left(\mu \mathrm{mol} \mathrm{O} \mathrm{g}^{-1} \mathrm{dw} \mathrm{h}^{-1}\right), I_{\mathrm{c}}$ and $I_{\mathrm{k}}\left(\mu \mathrm{mol}\right.$ quanta $\left.\left.\mathrm{m}^{-2} \mathrm{~s}^{-1}\right)\right]$. Means with different letters are statistically different at $P<0.05$ (bars represent standard error) 
Table 3 Summary of the twoway ANOVA testing the effects of salinity (30 and $50 \mathrm{psu}$ ) and temperature $\left(15,25\right.$, and $\left.35^{\circ} \mathrm{C}\right)$ treatments on photosynthetic parameters

\begin{tabular}{|c|c|c|c|c|c|}
\hline Parameter & Effect & $d f$ & MS & $F$ & $P$ \\
\hline \multirow{4}{*}{$\begin{array}{l}\alpha\left(\mu \mathrm{mol} \mathrm{O}_{2} \mathrm{~g}^{-1} \mathrm{dw} \mathrm{h}^{-1}\right) \\
\times\left(\mu \mathrm{mol} \text { quanta } \mathrm{m}^{-2} \mathrm{~s}^{-1}\right)^{-1}\end{array}$} & Salinity & 1 & 0.2428 & 0.06 & \multirow[t]{2}{*}{ ns } \\
\hline & Temperature & 2 & 26.2111 & 6.72 & \\
\hline & Salinity $\times$ Temperature & 2 & 1.4742 & 0.38 & ns \\
\hline & Error & 12 & 3.9003 & & \\
\hline \multirow{4}{*}{$P_{\max }\left(\mu \mathrm{mol} \mathrm{O} \mathrm{g}^{-1} \mathrm{dw} \mathrm{h}^{-1}\right)$} & Salinity & 1 & 701.78 & 0.06 & \multirow[t]{2}{*}{$\mathrm{ns}_{* *}$} \\
\hline & Temperature & 2 & 145409.78 & 11.54 & \\
\hline & Salinity $\times$ Temperature & 2 & 5287.74 & 0.42 & ns \\
\hline & Error & 12 & 12.605 .88 & & \\
\hline \multirow[t]{4}{*}{ Respiration $\left(\mu \mathrm{mol} \mathrm{O} \mathrm{O}_{2} \mathrm{~g}^{-1} \mathrm{dw} \mathrm{h}^{-1}\right)$} & Salinity & 1 & 6559.7325 & 10.30 & $* *$ \\
\hline & Temperature & 2 & 4983.8093 & 7.83 & $* *$ \\
\hline & Salinity $\times$ Temperature & 2 & 121.6380 & 0.19 & ns \\
\hline & Error & 12 & 636.7272 & & \\
\hline \multirow{4}{*}{$I_{\mathrm{c}}\left(\mu \mathrm{mol}\right.$ quanta $\left.\mathrm{m}^{-2} \mathrm{~s}^{-1}\right)$} & Salinity & 1 & 3.3819 & 14.72 & $* *$ \\
\hline & Temperature & 2 & 0.6711 & 2.92 & ns \\
\hline & Salinity $\times$ Temperature & 2 & 0.0168 & 0.07 & ns \\
\hline & Error & 12 & 0.2297 & & \\
\hline \multirow[t]{4}{*}{$I_{\mathrm{k}}\left(\mu \mathrm{mol}\right.$ quanta $\left.\mathrm{m}^{-2} \mathrm{~s}^{-1}\right)$} & Salinity & 1 & 97.9651 & 0.87 & \multirow[t]{2}{*}{$\mathrm{ns}_{*}$} \\
\hline & Temperature & 2 & 755.0299 & 6.72 & \\
\hline & Salinity $\times$ Temperature & 2 & 79.5368 & 0.71 & ns \\
\hline & Error & 12 & 112.2991 & & \\
\hline
\end{tabular}

$n s$ non-significant

${ }^{*} P<0.05 ;{ }^{* *} P<0.01$ times due to the small amount of plant tissue in each bottle $(0.0189-0.0377 \mathrm{~g} \mathrm{dw})$. At the end of the experiment plants were removed from the bottles, dried at $60^{\circ} \mathrm{C}$ for $48 \mathrm{~h}$, and subsequently weighed. Photosynthetic and respiratory rates were expressed in $\mathrm{mg} \mathrm{O}_{2}$ $\mathrm{g}^{-1} \mathrm{dw} \mathrm{h}^{-1}$.

\section{Statistical analyses}

Growth and mortality rates were evaluated using a twofactor ANOVA after testing for homogeneity of variance by Cochran's test (Underwood 1997). The experimental design considered salinity to be a fixed factor, with seven treatments $(0,10,20,30,40,50$, and $60 \mathrm{psu}$ ) in two different aquariums (a nested and a random factor) and with four plants (replicates) in each aquarium, so the linear model of sources of variance was defined as the following:

$$
\begin{aligned}
X_{i j n}= & \left.\mu+\operatorname{Salinity}_{i}+\operatorname{Aquarium}_{(\text {Salinity }}\right)_{j(i)} \\
& +\operatorname{Residual}_{n(i j)}
\end{aligned}
$$

Photosynthetic parameters were evaluated using a one-way ANOVA to assess salinity treatment effects (Eq. 1) or a two-factor orthogonal ANOVA to determine possible interactions between salinity and temperature or $\mathrm{pH}$ (Eq. 2).

$$
\begin{aligned}
X_{i j n}= & \mu+\text { Salinity }_{i}+\text { Residual }_{n(i j)} \\
X_{i j n}= & \mu+\text { Salinity }_{i}+\text { Factor }_{j}+\text { Salinity } \times \text { Factor }_{i j} \\
& + \text { Residual }_{n(i j)}
\end{aligned}
$$

When analysis of variance identified a significant difference for any factor, the post hoc test SNK (Student-Newman-Keuls) was applied to determine specific treatment differences. All calculations were performed using the GMAV.5 program (University of Sydney, Underwood and Chapman 1997). 


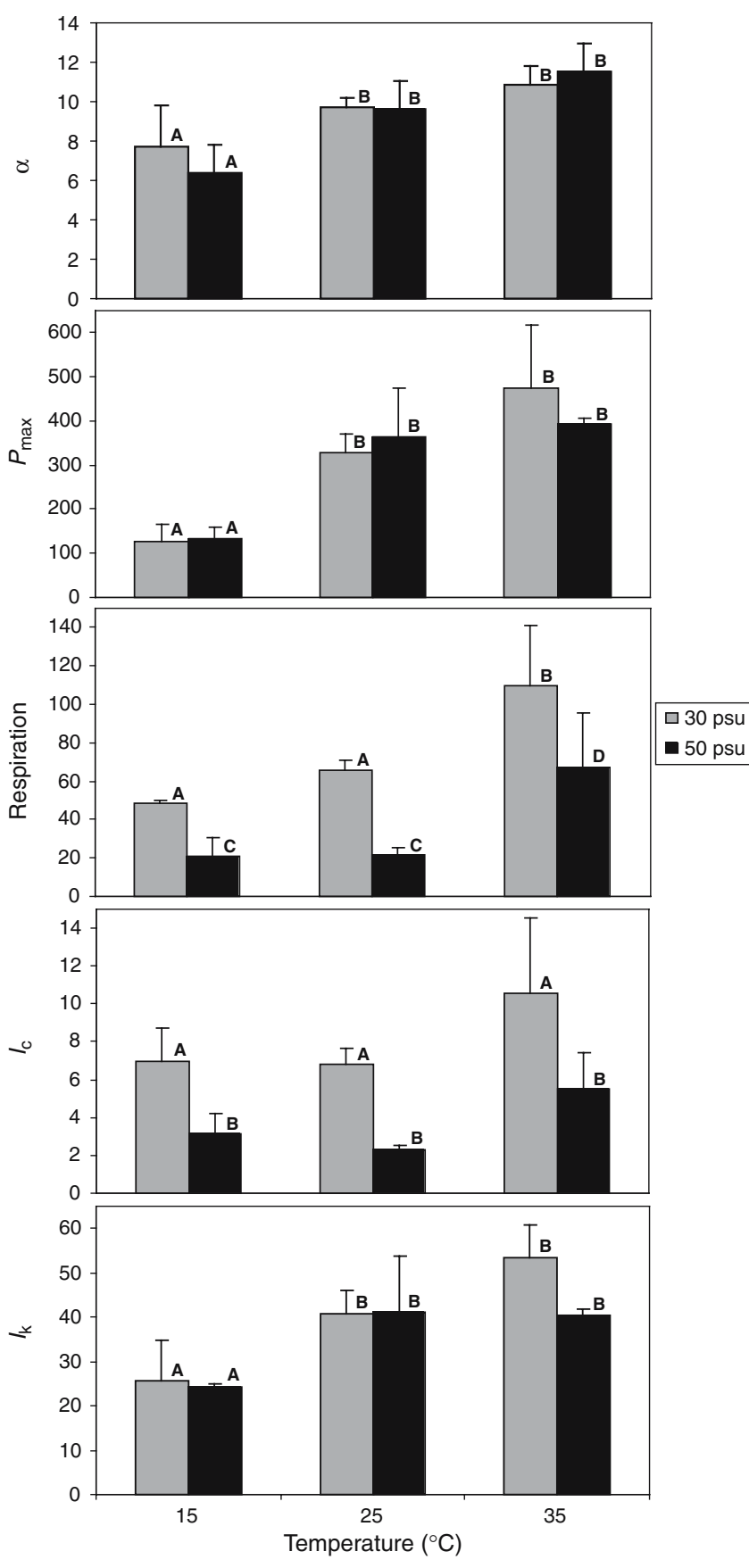

Fig. 6 Photosynthetic parameters (average and standard error) at different salinities and temperatures $\left[\alpha \quad\left(\mu \mathrm{mol} \quad \mathrm{O}_{2} \quad \mathrm{~g}^{-1} \mathrm{dw}\right.\right.$ $\left.\mathrm{h}^{-1}\right) \times\left(\mu \mathrm{mol} \text { quanta } \mathrm{m}^{-2} \mathrm{~s}^{-1}\right)^{-1}, P_{\max }$ and respiration rate $(\mu \mathrm{mol}$ $\left.\mathrm{O}_{2} \mathrm{~g}^{-1} \mathrm{dw} \mathrm{h} \mathrm{h}^{-1}\right), I_{\mathrm{c}}$ and $I_{\mathrm{k}}\left(\mu \mathrm{mol}\right.$ quanta $\left.\mathrm{m}^{-2} \mathrm{~s}^{-1}\right)$ ]. Means with different letters are statistically different at $P<0.05$

\section{Results}

Leaf production of $H$. johnsonii was affected by salinity. The relationship between growth and salinity is well described by a hyperbolic curve (Fig. 1), with an optimum value $\left(0.33\right.$ leaves plant ${ }^{-1}$ day $\left.^{-1}\right)$ at a salinity of
$30 \mathrm{psu}$, a significant reduction in higher and lower salinities (Table 1), and no growth at 0 and $60 \mathrm{psu}$. Mortality showed an opposite pattern (Fig. 1), with a minimum value $(37.5 \%)$ at 30 psu. All the plants died when exposed to freshwater ( $0 \mathrm{psu})$ and to the highest salinity concentration (60 psu).

Salinity also significantly affected the photosynthetic characteristics of this species (Table 2). All photosynthesis-irradiance curves exhibited a typical response (Figs. 2, 3, 4), with a rapid initial linear increase in oxygen release at low irradiances $(<100 \mu \mathrm{mol}$ quanta $\mathrm{m}^{-2} \mathrm{~s}^{-1}$ ), followed by a saturated photosynthetic rate at higher light intensities $\left(>100 \mu \mathrm{mol}\right.$ quanta $\mathrm{m}^{-2} \mathrm{~s}^{-1}$ ) and, in some cases, a photoinhibition $(>200 \mu \mathrm{mol}$ quanta $\mathrm{m}^{-2} \mathrm{~s}^{-1}$ ). Estimated photosynthetic efficiency at subsaturating light $(\alpha)$, maximum photosynthetic rate $\left(P_{\max }\right)$, and light-saturation point $\left(I_{\mathrm{k}}\right)$ showed higher values at salinities between 30 and 50 psu, with a maximum value at 40 psu for $\alpha$ and $P_{\max }$ (Fig. 5). $P_{\max }$ was totally depressed when plants were subjected to a salinity of 0 psu. Respiratory rates were more elevated at lower salinities ( $\leq 30 \mathrm{psu}$ ), decreasing at 40-60 psu (Fig. 5). The compensating irradiance $\left(I_{\mathrm{c}}\right)$ was maximum in freshwater, but no significant differences were found for other salinity treatments (Fig. 5).

No interactions between salinity and temperature were observed (Table 3 ). $P_{\max }, \alpha$, and $I_{\mathrm{k}}$ were significantly different as a function of temperature, with lower values at $15^{\circ} \mathrm{C}$ compared with those obtained at higher temperatures (Fig. 6). Dark respiration was also significantly affected by temperature, but with a similar response for 15 and $25^{\circ} \mathrm{C}$ and highest values for $35^{\circ} \mathrm{C}$. Although temperature effects on $I_{\mathrm{c}}$ were not significant, its response patterns were similar to those of other parameters, increasing with higher temperatures (Fig. 6).

A significant interaction $(P<0.05)$ was observed for $P_{\max }$ between salinity and $\mathrm{pH}$ (Table 4$): P_{\max }$ increased with $\mathrm{pH}=5$ at $30 \mathrm{psu}$, but not for other photosynthesisirradiance parameters. $\alpha$ showed a significant increase with low $\mathrm{pH}$ treatments. No significant differences were found in dark respiration, $I_{\mathrm{c}}$, and $I_{\mathrm{k}}$, but the trend was to obtain higher values at the lowest $\mathrm{pH}$ (Fig. 7). In the BOD bottles experiment, significant interactions between salinity and $\mathrm{pH}$ were not detected (Table 5). Although, there were no significant differences in photosynthetic rates, this parameter increased with lower $\mathrm{pH}$ values at $30 \mathrm{psu}$ (Fig. 8). At the same salinity, respiration rates decreased significantly with $\mathrm{pH}$ reduction, but at 40 psu this pattern was not so clear (Fig. 8).

\section{Discussion and conclusions}

Under laboratory conditions, $H$. johnsonii growth was similar to values recorded in the field (Kenworthy 1997), but mortality was relatively high in the control treatments $(37.5 \%)$. This was probably due to the experimental manipulations and the excision of plants into short segments. Despite this, significant differences in 
Table 4 Summary of the twoway ANOVA testing the effects of salinity (30 and $50 \mathrm{psu}$ ) and $\mathrm{pH}$ treatments $(5,6$, and 8.2$)$ on photosynthetic parameters

\begin{tabular}{|c|c|c|c|c|c|}
\hline Parameter & Effect & $d f$ & MS & $F$ & $P$ \\
\hline \multirow{4}{*}{$\begin{array}{l}\alpha\left(\mu \mathrm{mol} \mathrm{O} \mathrm{O}^{-1} \mathrm{dw} \mathrm{h}^{-1}\right) \\
\times\left(\mu \mathrm{mol} \text { quanta } \mathrm{m}^{-2} \mathrm{~s}^{-1}\right)^{-1}\end{array}$} & Salinity & 1 & 21.3170 & 1.81 & ns \\
\hline & $\mathrm{pH}$ & 2 & 56.3419 & 4.77 & \\
\hline & Salinity $\times \mathrm{pH}$ & 2 & 9.5833 & 0.81 & ns \\
\hline & Error & 12 & 11.8087 & & \\
\hline \multirow[t]{4}{*}{$P_{\max }\left(\mu \mathrm{mol} \mathrm{O} \mathrm{g}^{-1} \mathrm{dw} \mathrm{h}^{-1}\right)$} & Salinity & 1 & 48055.1871 & 4.08 & ns \\
\hline & $\mathrm{pH}$ & 2 & 70569.3603 & 5.99 & \\
\hline & Salinity $\times \mathrm{pH}$ & 2 & 62289.4690 & 5.29 & \\
\hline & Error & 12 & 11774.2802 & & \\
\hline \multirow[t]{4}{*}{ Respiration $\left(\mu \mathrm{mol} \mathrm{O} \mathrm{O}_{2} \mathrm{~g}^{-1} \mathrm{dw} \mathrm{h}^{-1}\right)$} & Salinity & 1 & 1582.1250 & 2.72 & ns \\
\hline & $\mathrm{pH}$ & 2 & 1419.5935 & 2.44 & ns \\
\hline & Salinity $\times \mathrm{pH}$ & 2 & 1910.7616 & 3.28 & ns \\
\hline & Error & 12 & 581.7553 & & \\
\hline \multirow{4}{*}{$I_{\mathrm{c}}\left(\mu \mathrm{mol}\right.$ quanta $\left.\mathrm{m}^{-2} \mathrm{~s}^{-1}\right)$} & Salinity & 1 & 26.8563 & 5.04 & * \\
\hline & $\mathrm{pH}$ & 2 & 0.7150 & 0.13 & ns \\
\hline & Salinity $\times \mathrm{pH}$ & 2 & 15.5100 & 2.91 & ns \\
\hline & Error & 12 & 5.3253 & & \\
\hline \multirow[t]{4}{*}{$I_{\mathrm{k}}\left(\mu \mathrm{mol}\right.$ quanta $\left.\mathrm{m}^{-2} \mathrm{~s}^{-1}\right)$} & Salinity & 1 & 771.9503 & 3.45 & ns \\
\hline & $\mathrm{pH}$ & 2 & 149.0064 & 0.67 & ns \\
\hline & Salinity $\times \mathrm{pH}$ & 2 & 655.2475 & 2.93 & ns \\
\hline & Error & 12 & 223.8274 & & \\
\hline
\end{tabular}

ns non-significant $P<0.05$
( $\alpha$ ), compared to those observed for other seagrasses (Hemminga and Duarte 2000; Touchette and Burkholder 2000). This could be due not only to a speciesspecific response but also to the fact that these plants were acclimated to low-irradiance greenhouse conditions for over 1 year prior to the experimentation (Major and Dunton 2000). Moreover, it has been observed that when PI parameters are calculated in laboratory conditions they are significantly different from those obtained in the field; values of $\alpha$ tend to be overestimated and $I_{\mathrm{k}}$ and $I_{\mathrm{c}}$ are underestimated when using laboratory-incubated plants (Major and Dunton 2000).

$H$. johnsonii is considered a rapid-growth plant with a reduced storage capacity, which implies that growth and photosynthetic rates should be closely coupled. However, in the present work a discrepancy between $P_{\max }$ and growth responses to salinity was observed. The highest $P_{\max }$ was observed at 40 psu while maximum growth was obtained at $30 \mathrm{psu}$. The differences may be a consequence of the differing exposure times, the different acclimation period used in the growth experiment, or the effect of using detached leaves for the PI curves versus whole plant segments for the growth measurements. They may also be due to toxicity of elevated salinities on meristematic tissues, affecting the growth of these plants (Zhu 2001). Thus, photosynthetic behavior could be a useful acute indicator of the response of a plant to a stress condition. However, a more comprehensive approach to determine the ecological salinity tolerance of a species would be to combine photosynthesis measurements with experiments to estimate growth or survival rates.

Our results suggest that $H$. johnsonii tolerates hypersaline conditions better than hyposaline conditions, although most seagrasses are thought to be more sensitive to increased salinity (Ogata and Matsui 1965; Biebl and McRoy 1971; Zieman 1975; Adams and Bate 1994; johnsonii exhibited low compensation $\left(I_{c}\right)$ and saturation points $\left(I_{\mathrm{k}}\right)$ with elevated photosynthetic efficiencies 


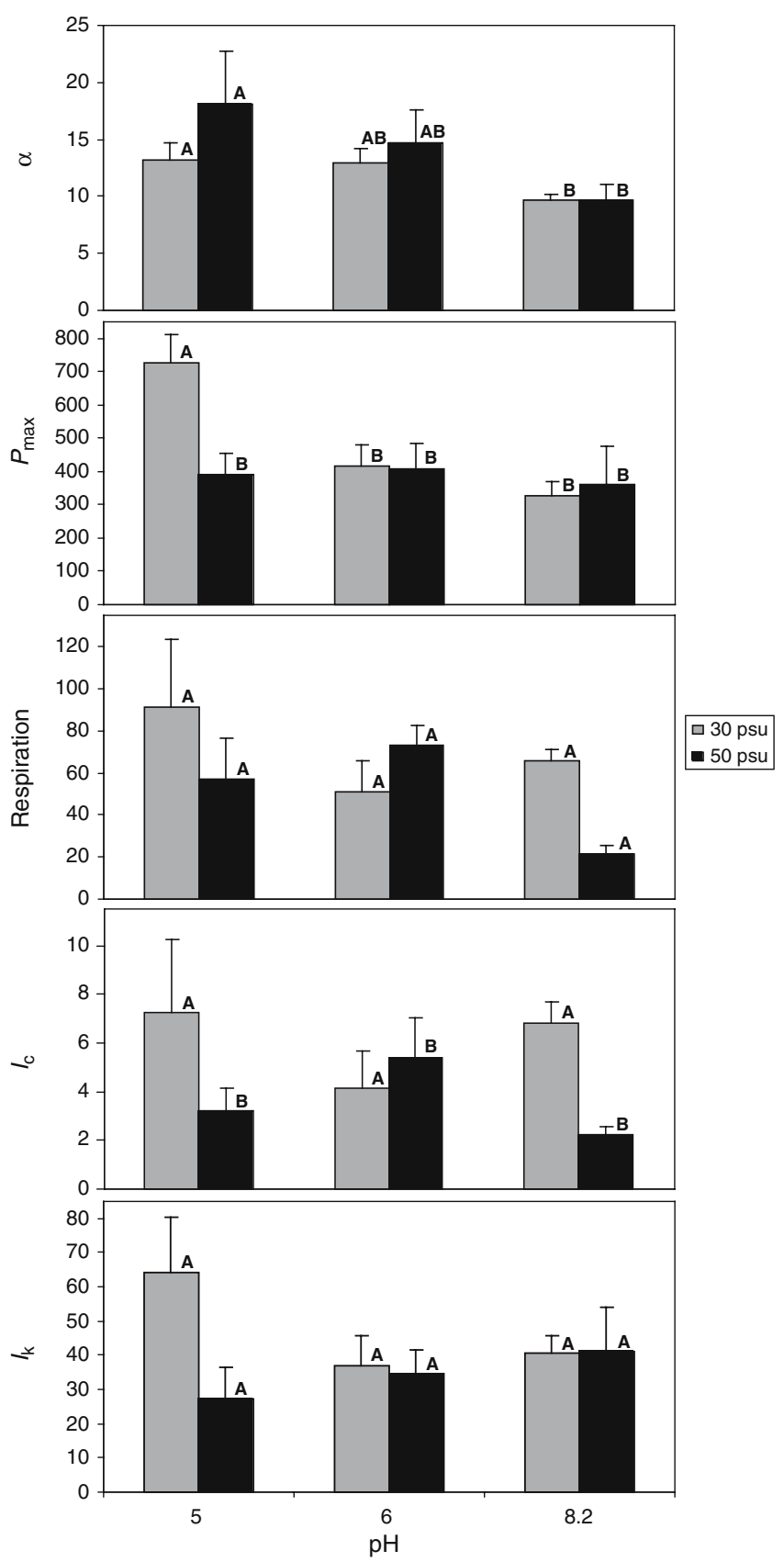

Fig. 7 Photosynthetic parameters (average and standard error) at different salinities and $\mathrm{pH}$ values $\left[\alpha\left(\mu \mathrm{mol} \mathrm{O} \mathrm{g}^{-1} \mathrm{dw} \mathrm{h}^{-1}\right) \times(\mu \mathrm{mol}\right.$ quanta $\left.\mathrm{m}^{-2} \mathrm{~s}^{-1}\right)^{-1}, P_{\max }$ and respiration rate $\left(\mu \mathrm{mol} \mathrm{O} \mathrm{O}^{-1} \mathrm{dw}\right.$ $\left.\mathrm{h}^{-1}\right), I_{\mathrm{c}}$ and $I_{\mathrm{k}}\left(\mu \mathrm{mol}\right.$ quanta $\left.\mathrm{m}^{-2} \mathrm{~s}^{-1}\right)$ ]. Means with different letters are statistically different at $P<0.05$

Doering and Chamberlain 1998; Kamermans et al. 1999; van Katwijk et al. 1999). Our results are consistent with Dawes et al. (1989), in which the photosynthetic responses of $H$. johnsonii and $H$. decipiens to salinity and temperature variations were compared. They concluded that $H$. johnsonii showed a broader tolerance than $H$. decipiens to temperature and salinity fluctuations.

Osmotic stress can change the sensitivity of seagrasses to other environmental conditions, such as temperature
Table 5 Summary of the two-way ANOVA testing the effects of salinity (30 and $50 \mathrm{psu})$ and $\mathrm{pH}$ treatments $(5,6,7$, and 8.2) on photosynthesis and dark respiration rates obtained with BOD bottles

\begin{tabular}{llllll}
\hline Parameter & Effect & $d f$ & MS & $F$ & $P$ \\
\hline Photosynthesis & Salinity & 1 & 3.1843 & 2.72 & $\mathrm{~ns}$ \\
& pH & 3 & 0.8764 & 0.75 & $\mathrm{~ns}$ \\
& Salinity $\times \mathrm{pH}$ & 3 & 1.9606 & 1.68 & $\mathrm{~ns}$ \\
\multirow{5}{*}{ Respiration } & Error & 16 & 1.1700 & & \\
& Salinity & 1 & 0.0149 & 3.90 & $\mathrm{~ns}$ \\
& pH & 3 & 0.0640 & 16.74 & $\mathrm{~ns}$ \\
& Salinity $\times \mathrm{pH}$ & 3 & 0.0123 & 3.21 & $\mathrm{~ns}$ \\
& Error & 16 & 0.0038 & & \\
\hline
\end{tabular}

$n_{* * *}$ non-significant $P<0.001$

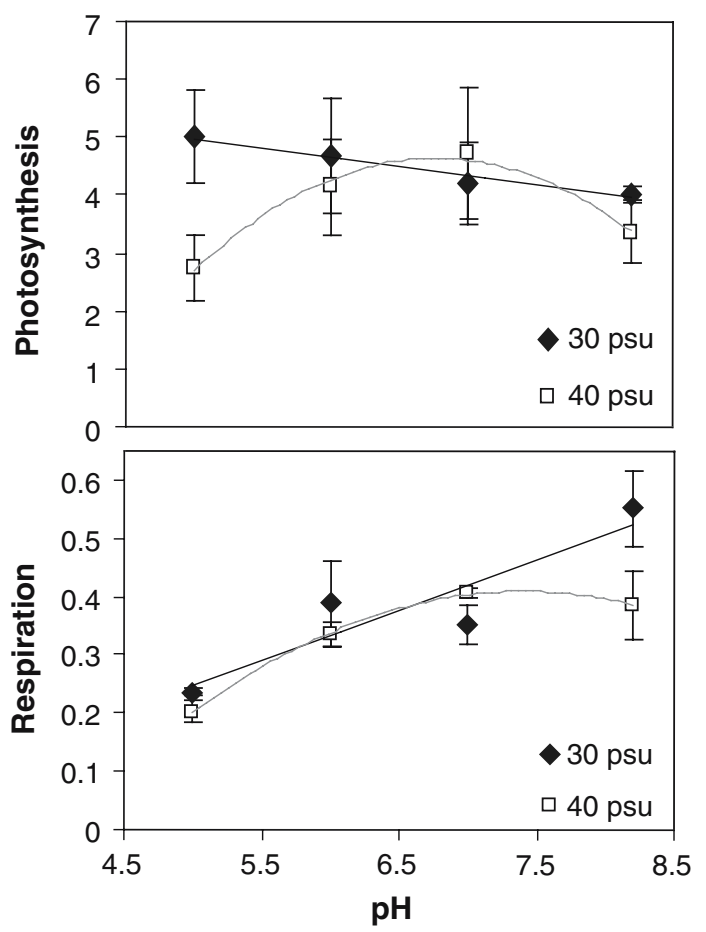

Fig. 8 Photosynthesis and dark respiration $\left(m g \mathrm{O}_{2} \mathrm{~g}^{-1} \mathrm{dw} \mathrm{h}^{-1}\right)$ rates (average and standard error) obtained with BOD bottles at different salinities (30 and $40 \mathrm{psu}$ ) and $\mathrm{pH}$ values $(5,6,7$, and 8.2$)$

increments, elevated light levels, or eutrophication (Biebl and McRoy 1971; Ralph 1999; van Katwijk et al. 1999; Vermaat et al. 2000). Biebl and McRoy (1971) found an increase in heat plasmatic resistance with increasing salinities for the subtidal forms of $Z$. marina, while Vermaat et al. (2000) observed increased mortality in $Z$. noltii when the temperature reached $20^{\circ} \mathrm{C}$ at higher experimental salinities. However, in the present work no interactions were detected in the photosynthetic responses of $H$. johnsonii in response to combined salinity and temperature treatments. 
Temperature is considered an important abiotic factor that can affect the metabolism of marine angiosperms (Drew 1979). Laboratory studies with some seagrasses have detected increasing photosynthetic and respiration rates at higher temperatures, with the maximum photosynthetic rates approximately doubling for every rise of $10^{\circ} \mathrm{C}$. For this study, all the PI parameters, except $I_{\mathrm{c}}$, increased significantly with temperature. $H$. johnsonii showed a photosynthetic optimum at 25$35^{\circ} \mathrm{C}$, the same optimal range that has been reported for several temperate seagrasses (Biebl and McRoy 1971; Drew 1979; Bulthuis 1987; Marsh et al. 1986).

In our work a slight interaction between salinity and $\mathrm{pH}$ for $P_{\max }$ was observed, but not for the remaining PI parameters. $P_{\max }$ increased significantly with the lowest $\mathrm{pH}$ treatment $(\mathrm{pH}=5)$ at $30 \mathrm{psu}$. Apart from minor direct effects of $\mathrm{pH}$ on photosynthesis by affecting the electrochemical gradients and proton flow across plasma membranes (Touchette and Burkholder 2000; Beer et al. 2001), the main effect of $\mathrm{pH}$ variation is that it alters the concentrations of the different dissolved inorganic carbon (DIC) forms (Beer et al. 1977). A decrease in $\mathrm{pH}$ in a closed system is expected to cause an increase in $\mathrm{CO}_{2}$ concentration and subsequently an increase in the photosynthetic rates of seagrasses (Beer and Waisel 1979; Invers et al. 1997). In the PI experiments, $P_{\max }$ and $\alpha$ values increased significantly when $\mathrm{pH}$ decreased $(\mathrm{pH}=5)$. $\mathrm{pH}$ reduction did not affect dark respiration, $I_{\mathrm{c}}$, and $I_{\mathrm{k}}$, similar to other studies (Invers et al. 1997). However, estimates of these parameters were highly variable. The results from the BOD bottle incubations showed that reduction in $\mathrm{pH}$ produced a significant decline in dark respiration, and although there were no significant differences in photosynthetic rates, an increase of this parameter with lower $\mathrm{pH}$ values at $30 \mathrm{psu}$ was observed. The differing responses observed between the PI curve experiments and the bottle incubations may be due to the different exposures of plants to the treatments. The first experiments were only of $1 \mathrm{~h}$ duration and two excised leaves were used, while in the second experiment four paired leaves with corresponding rhizomes were incubated for $20 \mathrm{~h}$. In addition, the closed chambers contained a small volume of media with the seagrass leaves oriented perpendicularly to the incident light, whilst the bottles used more diffuse light conditions in their incubations (Alcoverro et al. 1998).

Despite the potential limitations of these experiments, the results of this study show that the endemic seagrass $H$. johnsonii could be seriously affected by salinity alterations produced by human activities, such as freshwater management practices or the brine discharges from seawater desalination plants. However, salinity changes did not seem to alter the tolerance of this species to other environmental factors, such as temperature or $\mathrm{pH}$.

Acknowledgments This research was supported by a grant of the Generalitat Valenciana (CTESPR/2002/59). We would like to thank Amanda Kahn, Jennifer Kunzelman, and Robert York for assistance during the experiments and Rosanna Messina for her help with the first English manuscript.

\section{References}

Adams JB, Bate GC (1994) The ecological implications of tolerance to salinity by Ruppia cirrhosa (Petagna) Grande and Zostera capensis Setchell. Bot Mar 37:449-456

Alcoverro T, Manzanera M, Romero J (1998) Seasonal and agedependent variability of Posidonia oceanica (L.) Delile photosynthetic parameters. J Exp Mar Biol Ecol 230:1-13

Beer S, Waisel Y (1979) Some photosynthetic carbon fixation properties of seagrasses. Aquat Bot 7:129-138

Beer S, Eshel A, Waisel Y (1977) Carbon metabolism in seagrasses. I. Utilization of exogenous inorganic carbon species in photosynthesis. J Exp Bot 28:1180-1189

Beer S, Björk M, Gademman R, Ralph P (2001) Measurements of photosynthetic rates in seagrasses. In: Short FT, Coles RG (eds) Global seagrass research methods. Elsevier, Amsterdam, pp183-198

Biebl R, McRoy CP (1971) Plasmatic resistance of respiration and photosynthesis of Zostera marina at different salinities and temperatures. Mar Biol 8:48-56

Bulthuis DA (1987) Effects of temperature on photosynthesis and growth of seagrasses. Aquat Bot 27:27-40

Chesnes TC, Montague CL (2001) The effects of salinity fluctuation on the productivity and osmoregulation of two seagrass species. Estuarine research federation conference, November 4-8, 2001, St. Petersburg, FL

Dawes C, Chan M, Chinn R, Koch EW, Lazar A, Tomasko D (1987) Proximate composition, photosynthetic and respiratory responses of the seagrass Halophila engelmannii from Florida. Aquat Bot 27:195-201

Dawes CJ, Lobban CS, Tomasko DA (1989) A comparison of the physiological ecology of the seagrasses Halophila decipiens Ostenfeld and $H$. johnsonii Eiseman from Florida. Aquat Bot 33:149-154

Doering PH, Chamberlain RH (1998) Experimental studies on the salinity tolerance of turtle grass, Thalassia testudinum. In: Workshop on seagrasses. Subtropical and tropical seagrass management ecology: responses to environmental stress. Fort Myers, FL

Drew EA (1979) Physiological aspects of primary production in seagrasses. Aquat Bot 7:139-150

Drysdale FR, Barbour MG (1975) Response of the marine angiosperm Phyllospadix torreyi to certain environmental variables: a preliminary study. Aquat Bot 1:97-106

Durako M, Wettstein F (1994) Johnson's seagrass: the Rodney dangerfield of seagrasses. Palmetto 14(3):3-5

Durako MJ, Kenworthy WJ, Fatemy SMR, Valavi H, Thayer GW (1993) Assessment of the toxicity of Kuwait crude oil on the physiology of the seagrasses of the northern Persian Gulf. Mar Poll Bull 27:223-227

Durako MJ, Kunzelman JI, Kenworthy WJ, Hammerstrom KK (2003) Depth-related variability in the photobiology of two populations of Halophila johnsonii and Halophila decipiens. Mar Biol 142:1219-1228

Eiseman NJ, McMillan C (1980) A new species of seagrass, Halophila johnsonii, from the Atlantic coast of Florida. Aquat Bot 9:15-19

Hellblom F, Björk M (1999) Photosynthetic responses in Zostera marina to decreasing salinity, inorganic carbon and osmolality. Aquat Bot 65:97-104

Hemminga M, Duarte CM (2000) Seagrass ecology. Cambridge University Press, Cambridge

Hillman K, McComb AJ, Walker DI (1995) The distribution, biomass and primary production of the seagrass Halophila ovalis in the Swan/Canning Estuary, Western Australia. Aquat Bot 51:1-54 
Invers O, Romero J, Pérez M (1997) Effects of pH on seagrass photosynthesis: a laboratory and field assessment. Aquat Bot 59:185-194

Kamermans P, Hemminga MA, de Jong DJ (1999) Significance of salinity and silicon levels for growth of a formerly estuarine eelgrass (Zostera marina) population (Lake Grevelingen, The Netherlands). Mar Biol 133:527-539

van Katwijk MM, Schmitz GHW, Gasseling AP, van Avesaath PH (1999) Effects of salinity and nutrient load and their interaction on Zostera marina. Mar Ecol Prog Ser 190:155-165

Kenworthy WJ (1997) An updated biological status review and summary of the proceedings of a workshop to review the biological status of the seagrass, Halophila johnsonii Eiseman. Rept. office of protected resources, national marine fisheries service, Silver Spring, MD

Kerr EA, Strother S (1985) Effects of irradiance, temperature and salinity on photosynthesis of Zostera muelleri. Aquat Bot 23:177-183

Kraemer GP, Chamberlain RH, Doering PH, Steinman AD, Hanisak M (1999) Physiological responses of transplant of the freshwater angiosperm Vallisneria americana along a salinity gradient in the Caloosahatchee Estuary (Southwestern Florida). Estuaries 22(1):138-148

Lattemann S, Höpner T (2003) Seawater desalination. Impacts of brine and chemical discharges on the marine environment. Desalination Publications, L'Aquila

Major KM, Dunton KH (2000) Photosynthetic performance in Syringodium filiforme: seasonal variation in light-harvesting characteristics. Aquat Bot 68:249-264

Marsh JA, Dennison WC, Alberte RS (1986) Effects of temperature on photosynthesis and respiration in eelgrass (Zostera marina L.). J Exp Mar Biol Ecol 101:257-267

McMillan C, Moseley FN (1967) Salinity tolerances of five marine spermatophytes of Redfish Bay, Texas. Ecology 48(3):503-506

Montague CL, Ley JA (1993) A possible effect of salinity fluctuation on abundance of benthic vegetation and associated fauna in Northeastern Florida Bay. Estuaries 16:703-717

Ogata E, Matsui T (1965) Photosynthesis in several marine plants of Japan as affected by salinity, drying and $\mathrm{pH}$, with attention to their growth habitats. Bot Mar 8:199-217

Pinnerup SP (1980) Leaf production of Zostera marina L. at different salinities. Ophelia (Suppl 1):219-224
Ralph PJ (1998) Photosynthetic responses of Halophila ovalis (R. Br.) Hook. f. to osmotic stress. J Exp Mar Biol Ecol 227:203220

Ralph PJ (1999) Photosynthetic response of Halophila ovalis (R.Br.) Hook. $f$. to combined environmental stress. Aquat Bot 65:83-96

Ramage DL, Schiel DR (1998) Reproduction in the seagrass Zostera novazelandica on intertidal platforms in southern New Zealand. Mar Biol 130:479-489

Short FT, Duarte CM (2001) Methods for the measurement of seagrass growth and production. In: Short FT, Coles RG (eds) Global seagrass research methods. Elsevier, Amsterdam, pp 155-182

Sibly RM, Calow P (1989) A life-cycle theory of responses to stress. In: Calow P, Berry RJ (eds) Evolution ecology and environmental stress. Biol J Linnean Soc 37:101-116

Simon C, Ar Gall E, Levavasseur G, Deslandes E (1999) Effects of short-term variations of salinity and temperature on the photosynthetic response of the red alga Grateloupia doryphora from Brittany (France). Bot Mar 42:437-440

Touchette BW, Burkholder JM (2000) Overview of the physiological ecology of carbon metabolism in seagrasses. J Exp Mar Biol Ecol 250:169-205

Underwood AJ (1997) Experiments in ecology. Their logical design and interpretation using analysis of variance. Cambridge University Press, Cambridge

Vermaat JE, Verhagen FCA, Lindenburg D (2000) Contrasting responses in two populations of Zostera noltii Hornem. to experimental photoperiod manipulation at two salinities. Aquat Bot 67:179-189

Walker DI (1985) Correlations between salinity and growth of the seagrass Amphibolis antarctica (Labill.) Sonder and Aschers., in Shark Bay, Western Australia, using a new method for measuring production rate. Aquat Bot 23:13-26

Walker DI, McComb AJ (1990) Salinity response of the seagrass Amphibolis antarctica (Labill.) Sonder et Aschers.: an experimental validation of field results. Aquat Bot 36:359-366

Wortmann J, Hearne JW, Adams JB (1997) A mathematical model of an estuarine seagrass. Ecol Model 98:137-149

Zhu JK (2001) Plant salt tolerance. Trends Plant Sci 6(2):66-71

Zieman JC (1975) Seasonal variation of turtle grass, Thalassia testudinum König, with reference to temperature and salinity effects. Aquat Bot 1:107-123 